\title{
ANTIFUNGAL MACROCYCLIC POLYLACTONES FROM Penicillium verruculosum
}

\author{
Jens Breinholt*, Georg W. Jensen and Ruby I. Nielsen \\ Novo Nordisk A/S, Plant Protection Division, \\ Novo Alle, DK-2880 Bagsværd, Denmark \\ Carl E. Olsen
}

Royal Veterinary and Agricultural University, Chemistry Department, 40 Thorvaldsensvej, DK-1871 Frederiksberg C, Denmark

JENS C. FRISVAD

The Technical University of Denmark, Department of Biotechnology, DK-2800 Lyngby, Denmark

(Received for publication February 1, 1993)

\begin{abstract}
Three macrocyclic polylactones have been isolated from Penicillium verruculosum. Two were found to be novel and the third to be identical with NG-012'? Their structures were elucidated by spectroscopic and chemical methods. A full assignment of ${ }^{1} \mathrm{H}$ - and ${ }^{13} \mathrm{C}$-resonances in acetone- $d_{6}$ are given for all three compounds. The compounds show antifungal activity.
\end{abstract}

During ongoing screening for antifungal metabolites of potential interest for agricultural applications Penicillium verruculosum (IMI 352119) was found to produce three closely related macrocyclic polylactones, BK223-A, BK223-B and BK223-C. BK223-A was identified as NG-012, a nerve growth factor potentiator isolated from Penicillium verruculosum F-4542 ${ }^{1}$. BK223-B and BK223-C, however, were found to be novel. The compounds all exhibit growth inhibiting activity against plant pathogenic fungi including Botrytis cinerea, Phoma lingam, Phoma betae, Pyrenophora teres, Sclerotinia sclerotiorum, Monilinia fructigena, Ascochyta pisi and Alternaria alternata. We report on the production, isolation, chemical structure and biological activities of the compounds.

\section{Description of the Strain and Taxonomy}

Strain IMI 352119 was allocated to Penicillium verruculosum Peyronel. In subgenus Biverticillium thick sphaeroidal verrucose conidium walls are only found in $P$. purpurogenum Stoll, $P$. verruculosum, $P$. aculeatum Raper \& Fennell and $P$. proteolyticum Kamyschko. IMI 352119 typically produced rather divergent metulae and ampulliform-acerose phialides typical for $P$. verruculosum and $P$. aculeatum. The two latter species have occasionally been synonymised ${ }^{2}$, but can be distinguished by their growth rate on Czapek yeast autolysate agar at $37^{\circ} \mathrm{C}$. The former has colony diameters more than $16 \mathrm{~mm}$ after one week, whereas diameters of the latter species are always less than $8 \mathrm{~mm}$ at the same conditions.

Screening for Other Producers of BK223-A

Representative isolates of all species in Penicillium subgenus Biverticillium and the closely related teleomorphic state Talaromyces C. R. Benjamin were screened for BK223-A by the method of FRISVAD and THRANE ${ }^{3)}$ and only the following strains were found to be producers: P. verruculosum IMI 352119 , 
FRR 635 (=IMI $68239=$ CBS $312.59=$ ATCC $18315=$ IFO 5728, ex type of $P$. aculeatum var. apiculatum Abe), CBS 548.73 and CBS 264.67 (both allocated to P. aculeatum by CBS before the two species were synonymised by STOLK and SAMSON in $1983^{21}$ ). However, all these producers of BK223-A had copious yellow mycelium on malt agars and grew strongly at $37^{\circ} \mathrm{C}$, indicating $P$. verruculosum. It cannot be excluded that what $\mathrm{ABE}$ described as $P$. aculeatum var. apiculatum is a good taxon, in which case it should be validated, or that these BK223-A producers represent the anamorphic state of Talaromyces panasenkoi Pitt. The strain CBS 583.72B was the only strain in Talaromyces found to produce BK223-A, however this strain is kept as T. ucrainicus Udagawa at the CBS and IFO culture collections.

Production and Isolation

Penicillium verruculosum (IMI 352119) was fermented in Erlenmeyer flasks as either surface or submerged culture. The metabolites were extracted from the cultures with methanol, and BK223-A, -B and $-\mathrm{C}$ were isolated by EtOAc extraction followed by reversed phase chromatography as described in the experimental part. Twenty fermentation flasks yielded 128, 52 and $28 \mathrm{mg}$ of BK223-A, $-\mathrm{B}$ and $-\mathrm{C}$, respectively.

\section{Characterization and Structure}

The physical and chemical properties recorded for BK223-A, -B and -C are presented in Table 1, and the ${ }^{1} \mathrm{H}$ and ${ }^{13} \mathrm{C}$ NMR data are listed in Tables 2 and 3, respectively.

Comparison of the three metabolites by UV, IR, NMR and MS showed that the compounds were structurally closely related. ${ }^{1} \mathrm{H}-{ }^{1} \mathrm{H}-$ and ${ }^{1} \mathrm{H}_{-}{ }^{13} \mathrm{C}$-correlation spectroscopy revealed that each of the three metabolites was composed of two identical 2,4-hydroxylated aromatic acids and three $\mathrm{C}_{4}$-hydroxy acid units. Given the molecular compositions, as determined by HR-LSIMS, in conjunction with ${ }^{13} \mathrm{C}$ NMR data, the connections between the five units had to be ester linkages. By alkaline hydrolysis followed by derivatization with bis(trimethylsilyl)trifluoroacetamid (BSTFA), the $\mathrm{C}_{4}$-hydroxy acids were identified as their trimethylsilyl derivatives by GC/MS. BK223-A and -B both yielded two equivalents of 3-hydroxybutyric acid and one 3,4-dihydroxybutyric acid, whereas BK223-C, in accordance with the molecular composition showing one less oxygen, yielded only 3 -hydroxybutyric acid.

The aromatic acid component was isolated from the hydrolysis mixture by acidification, extraction and subsequent reversed phase HPLC. The compound was identified as (3R)-3,4-dihydro-6,8-dihydroxy3-methyl-isocoumarin by comparison of its spectral and physical data with literature values ${ }^{4)}$. The lactone is formed from the corresponding hydroxy acid during the acidic work-up.

Table 1. Physical and spectroscopic data for compounds 1, 2 and $\mathbf{3 .}$

\begin{tabular}{lccc}
\hline \multicolumn{1}{c}{ Compound } & $\mathbf{1}$ & $\mathbf{2}$ & $\mathbf{3}$ \\
\hline Molecular formula: & $\mathrm{C}_{32} \mathrm{H}_{38} \mathrm{O}_{15}$ & $\mathrm{C}_{32} \mathrm{H}_{38} \mathrm{O}_{15}$ & $\mathrm{C}_{32} \mathrm{H}_{38} \mathrm{O}_{14}$ \\
Molecular weight: & 662 & 662 & 646 \\
HR-LSIMS $(\mathrm{M}+\mathrm{H})^{+}$ & & & \\
$\quad$ Calcd: & 663.2289 & 663.2289 & 647.2340 \\
$\quad$ Found: & 663.2300 & 663.2307 & 647.2333 \\
$\mathrm{UV}^{\mathrm{a}}\left(\lambda_{\max } \mathrm{nm}(\log \varepsilon), \mathrm{MeOH}\right)$ & & $303(4.0), 265(4.3)$ and $217(4.6)$ & $-21^{\circ}(0.4)$ \\
{$[\alpha]_{\mathrm{D}}^{22}(c)$ in $\mathrm{MeOH}$} & $-22^{\circ}(1.0)$ & $-5^{\circ}(0.8)$ & \\
$\mathrm{IR}^{\mathbf{a}}\left(v_{\max } \mathrm{cm}^{-1}, \mathrm{KBr}\right)$ & & $3400,1735,1650,1620,1590$, & \\
& & $1451,1374,1335,1313,1260$, & \\
& & 1191,1057 & \\
\end{tabular}

a UV and IR-data very similar. 
Table 2. ${ }^{1} \mathrm{H}$ NMR data in acetone- $d_{6}$ for compounds 1,2 and 3.

\begin{tabular}{|c|c|c|c|}
\hline & $\begin{array}{l}\text { Compound } 1 \\
\delta(\mathrm{m}, J)\end{array}$ & $\begin{array}{l}\text { Compound } 2 \\
\delta(\mathrm{m}, J)\end{array}$ & $\begin{array}{l}\text { Compound } \mathbf{3} \\
\delta(\mathrm{m}, J)\end{array}$ \\
\hline $\mathrm{H}-\mathrm{C} 4$ & $6.29(\mathrm{~d}, 2.5)$ & $6.30(\mathrm{~d}, 2.5)$ & $6.29(\mathrm{~d}, 2.5)$ \\
\hline $\mathrm{H}-\mathrm{C} 6$ & $6.37(\mathrm{~d}, 2.5)$ & $6.38(\mathrm{~d}, 2.5)$ & $6.37(\mathrm{~d}, 2.5)$ \\
\hline $\mathrm{H}_{2}-\mathrm{C} 8$ & $3.47(\mathrm{dd}, 7 / 13), 2.99(\mathrm{dd}, 8 / 13)$ & $3.58(\mathrm{dd}, 7 / 13), 2.90(\mathrm{dd}, 7 / 13)$ & $3.50(\mathrm{dd}, 7 / 13), 2.96(\mathrm{dd}, 8 / 13)$ \\
\hline $\mathrm{H}-\mathrm{C} 9$ & $5.02(\mathrm{~m})$ & $5.04(\mathrm{~m})$ & $5.02(\mathrm{~m})$ \\
\hline $\mathrm{H}_{3}-\mathrm{C} 10$ & $1.19(\mathrm{~d}, 6)$ & $1.18(\mathrm{~d}, 6)$ & $1.19(\mathrm{~d}, 6)$ \\
\hline $\mathrm{H}_{2}-\mathrm{C} 12$ & 2.76 (AB-mult) & $2.55(\mathrm{dd}, 5 / 16), 2.46(\mathrm{dd}, 8 / 16)$ & $2.64(\mathrm{~d}, 7)$ \\
\hline $\mathrm{H}-\mathrm{C} 13$ & $5.29(\mathrm{~m})$ & $4.23(\mathrm{~m})$ & $5.28(\mathrm{~m})$ \\
\hline $\mathrm{H}_{2 / 3}-\mathrm{Cl} 4$ & $3.66(\mathrm{~d}, 5)$ & $4.20(\mathrm{dd}, 5 / 1 \mathrm{l}), 4.06(\mathrm{dd}, 5 / 11)$ & $1.28(\mathrm{~d}, 6)$ \\
\hline $\mathrm{H}_{2}-\mathrm{Cl} 6$ & 2.79 (n.d.), 2.90 (n.d.) & $2.96(\mathrm{dd}, 8 / 16), 2.84(\mathrm{dd}, 5 / 16)$ & $2.91(\mathrm{dd}, 7 / 16), 2.74(\mathrm{dd}, 7 / 16)$ \\
\hline $\mathrm{H}-\mathrm{Cl} 7$ & $5.55(\mathrm{~m})$ & $5.58(\mathrm{~m})$ & $5.54(\mathrm{~m})$ \\
\hline $\mathrm{H}_{3}-\mathrm{Cl} 8$ & $1.45(\mathrm{~d}, 6)$ & $1.48(\mathrm{~d}, 6)$ & $1.45(\mathrm{~d}, 6)$ \\
\hline $\mathrm{H}-\mathrm{C} 22$ & $6.30(\mathrm{~d}, 2.5)$ & $6.29(\mathrm{~d}, 2.5)$ & $6.31(\mathrm{~d}, 2.5)$ \\
\hline $\mathrm{H}-\mathrm{C} 24$ & $6.36(\mathrm{~d}, 2.5)$ & $6.37(\mathrm{~d}, 2.5)$ & $6.35(\mathrm{~d}, 2.5)$ \\
\hline $\mathrm{H}_{2}-\mathrm{C} 26$ & $3.58(\mathrm{dd}, 6 / 13), 2.79(8 / 13)$ & $3.41(\mathrm{dd}, 7 / 13), 3.10(\mathrm{dd}, 8 / 13)$ & $3.60(\mathrm{dd}, 6 / 13), 2.78(\mathrm{dd}, 9 / 13)$ \\
\hline $\mathrm{H}-\mathrm{C} 27$ & $5.02(\mathrm{~m})$ & 5.15 (seks, 7$)$ & $5.03(\mathrm{~m})$ \\
\hline $\mathrm{H}_{3}-\mathrm{C} 28$ & $1.15(\mathrm{~d}, 6)$ & $1.24(\mathrm{~d}, 6)$ & $1.13(\mathrm{~d}, 6)$ \\
\hline $\mathrm{H}_{2}-\mathrm{C} 30$ & 2.77 (AB-mult), 2.89 (AB-mult) & $2.95(\mathrm{dd}, 6 / 16), 2.78(\mathrm{dd}, 8 / 16)$ & $2.92(\mathrm{dd}, 6 / 16), 2.72(\mathrm{dd}, 7 / 16)$ \\
\hline $\mathrm{H}-\mathrm{C} 31$ & $5.55(\mathrm{seks}, 6)$ & $5.53(\mathrm{~m})$ & $5.55(\mathrm{~m})$ \\
\hline $\mathrm{H}_{3}-\mathrm{C} 32$ & $1.46(\mathrm{~d}, 6)$ & $1.44(\mathrm{~d}, 6)$ & $1.44(\mathrm{~d}, 6)$ \\
\hline
\end{tabular}

$\delta$-Values in ppm relative to internal TMS, $J$-values in $\mathrm{Hz}$.

n.d.: Not determined.

Table $3 .{ }^{13} \mathrm{C}$ NMR data in acetone- $d_{6}$ for compounds 1, 2 and 3.

\begin{tabular}{cccc|cccc}
\hline Position & $\begin{array}{c}\text { Compound 1 } \\
\delta(\mathrm{m})\end{array}$ & $\begin{array}{c}\text { Compound 2 } \\
\delta(\mathrm{m})\end{array}$ & $\begin{array}{c}\text { Compound 3 } \\
\delta(\mathrm{m})\end{array}$ & Position & $\begin{array}{c}\text { Compound 1 } \\
\delta(\mathrm{m})\end{array}$ & $\begin{array}{c}\text { Compound 2 } \\
\delta(\mathrm{m})\end{array}$ & $\begin{array}{c}\text { Compound 3 } \\
\delta(\mathrm{m})\end{array}$ \\
\hline C1 & $171.26(\mathrm{~s})$ & $171.32(\mathrm{~s})$ & $171.25(\mathrm{~s})$ & $\mathrm{C} 17$ & $69.90(\mathrm{~d})$ & $70.23(\mathrm{~d})$ & $69.94(\mathrm{~d})$ \\
C2 & $106.03(\mathrm{~s})$ & $106.32(\mathrm{~s})$ & $105.99(\mathrm{~s})$ & $\mathrm{C} 18$ & $20.11(\mathrm{q})$ & $20.03(\mathrm{q})$ & $20.14(\mathrm{q})$ \\
C3 & $163.26(\mathrm{~s})$ & $163.03(\mathrm{~s})$ & $163.35(\mathrm{~s})^{\mathrm{a}}$ & C19 & $170.91(\mathrm{~s})$ & $171.39(\mathrm{~s})$ & $170.99(\mathrm{~s})$ \\
C4 & $102.65(\mathrm{~d})$ & $102.50(\mathrm{~d})$ & $102.70(\mathrm{~d})$ & C20 & $105.54(\mathrm{~s})$ & $105.82(\mathrm{~s})$ & $105.57(\mathrm{~s})$ \\
C5 & $165.85(\mathrm{~s})$ & $165.48(\mathrm{~s})$ & $165.94(\mathrm{~s})$ & C21 & $163.20(\mathrm{~s})^{\mathrm{a}}$ & $163.20(\mathrm{~s})$ & $163.29(\mathrm{~s})$ \\
C6 & $112.77(\mathrm{~d})$ & $112.74(\mathrm{~d})$ & $112.85(\mathrm{~d})$ & C22 & $102.85(\mathrm{~d})$ & $102.50(\mathrm{~d})$ & $102.83(\mathrm{~d})$ \\
C7 & $143.34(\mathrm{~s})$ & $143.38(\mathrm{~s})$ & $143.30(\mathrm{~s})$ & C23 & $166.17(\mathrm{~s})$ & $166.07(\mathrm{~s})$ & $166.22(\mathrm{~s})$ \\
C8 & $41.64(\mathrm{t})$ & $41.73(\mathrm{t})$ & $41.73(\mathrm{t})$ & C24 & $113.60(\mathrm{~d})$ & $112.14(\mathrm{~d})$ & $113.55(\mathrm{~d})$ \\
C9 & $73.35(\mathrm{~d})$ & $72.66(\mathrm{~d})$ & $73.30(\mathrm{~d})$ & C25 & $143.20(\mathrm{~s})$ & $143.52(\mathrm{~s})$ & $143.23(\mathrm{~s})$ \\
C10 & $19.57(\mathrm{q})$ & $19.80(\mathrm{q})$ & $19.54(\mathrm{q})$ & C26 & $42.59(\mathrm{t})$ & $41.39(\mathrm{t})$ & $42.59(\mathrm{t})$ \\
C11 & $170.59(\mathrm{~s})$ & $171.07(\mathrm{~s})$ & $170.28(\mathrm{~s})$ & C27 & $72.49(\mathrm{~d})$ & $72.83(\mathrm{~d})$ & $72.42(\mathrm{~d})$ \\
C12 & $36.36(\mathrm{t})$ & $39.90(\mathrm{t})$ & $40.97(\mathrm{t})$ & C28 & $19.40(\mathrm{q})$ & $19.66(\mathrm{q})$ & $19.49(\mathrm{q})$ \\
C13 & $72.27(\mathrm{~d})$ & $66.72(\mathrm{~d})$ & $68.41(\mathrm{~d})$ & C29 & $170.16(\mathrm{~s})$ & $170.50(\mathrm{~s})$ & $170.14(\mathrm{~s})$ \\
C14 & $63.23(\mathrm{t})$ & $68.22(\mathrm{t})$ & $19.89(\mathrm{q})$ & C30 & $40.92(\mathrm{t})$ & $40.94(\mathrm{t})$ & $40.63(\mathrm{t})$ \\
C15 & $170.32(\mathrm{~s})$ & $170.70(\mathrm{~s})$ & $170.11(\mathrm{~s})$ & C31 & $69.95(\mathrm{~d})$ & $70.00(\mathrm{~d})$ & $69.98(\mathrm{~d})$ \\
C16 & $40.51(\mathrm{t})$ & $40.67(\mathrm{t})$ & $41.01(\mathrm{t})$ & C32 & $20.20(\mathrm{q})$ & $20.03(\mathrm{q})$ & $20.00(\mathrm{q})$ \\
\hline
\end{tabular}

$\delta$-Values in ppm relative to internal TMS $(0.0 \mathrm{ppm})$.

a Might be interchanged.

The $\mathrm{C}_{4}$-fragments and the aromatic units could be joined by observing long range ${ }^{1} \mathrm{H}^{13} \mathrm{C}$-couplings to carbonyl carbon atoms from $\alpha$ - and $\beta$-protons in the same unit and from protons in neighbouring units across the oxygen atom in the ester linkages. Additional long range correlations from the side chain protons $\left(\mathrm{H}_{2}-\mathrm{C} 8\right.$ and $\left.\mathrm{H}_{2}-\mathrm{C} 26\right)$ to carbon atoms in the aromatic nuclei $(\mathrm{C} 2, \mathrm{C} 6$ and $\mathrm{C} 7$ and $\mathrm{C} 20, \mathrm{C} 24$ and $\mathrm{C} 25$, respectively) in combination with correlations within the aromatic systems, support the structures 1,2 and 3 for BK223-A, -B and -C, respectively. The observed correlations allow the full assignment of the ${ }^{1} \mathrm{H}$ - and 
${ }^{13} \mathrm{C}$-resonances, as given in Tables 2 and 3. The NMR-techniques used include the COLOC-experiment and selective INEPT experiments together with ${ }^{1} \mathrm{H}$-detected ${ }^{1} \mathrm{H}^{-13} \mathrm{C}$-correlation experiments (HMQC/ $\mathrm{HMBC}$ ). The structures for the three compounds are shown in Fig. 1.

The suggested structural difference between 1 and 2 is in accordance with the HMBC-data; $\mathrm{H}_{2}-\mathrm{Cl} 4$ in 2 show correlation to the C15 carbonyl group (170.70 ppm), whereas no such correlation is observed for 1 .

Acetylation of 1 and 2 yielded the corresponding pentaacetates (LSIMS $\mathrm{MH}^{+}$873), 1a and $\mathbf{2 a}$, respectively. The ${ }^{1} \mathrm{H}$ NMR spectra of the derivatives (1a) and (2a) confirm the positions of the free hydroxy groups, i.e. show the expected downfield shifts for the protons attached to the carbon atom bearing the hydroxyl group: the methylene protons at $\mathrm{C} 14$ in 1 at $\delta 3.66$ appear in 1a at $\delta 4.08 \sim 4.37(\Delta \delta-0.42$ and -0.71 ), and the methine proton attached to $\mathrm{C} 13$ in 2 at $\delta 4.23$ shifts downfield in $\mathbf{2 a}$ to $\delta 5.34(\Delta \delta-1.11)$. The ${ }^{1} \mathrm{H}$-signals in the 3,4-dihydroxybutyric acid residues of $1 \mathrm{a}$ and 2a, that is $\mathrm{H}_{2}-\mathrm{Cl}$, $\mathrm{H}-\mathrm{C} 13$ and $\mathrm{H}_{2}-\mathrm{Cl}$, are easily assigned from the ${ }^{1} \mathrm{H}^{-1} \mathrm{H}$-COSY spectra as shown in Fig. 2. As expected the chemical shifts for 1a and $\mathbf{2 a}$ are in this part of the molecule very close, since both hydroxy groups carry an acyl group and only steric factors contribute to the chemical shift differences between 1a and $\mathbf{2 a}$. The complete ${ }^{1} \mathrm{H}$ NMR data for the derivatives are given in the experimental part.

The absolute configuration of $\mathrm{C} 3$ in all the 3-hydroxybutyric acid residues was determined to be $R$ by acid catalyzed ethanolysis, derivatization with $(S)$-phenylethylisocyanate followed by GC-separation of the diastereomers ${ }^{5)}$. The absolute configuration of the 3,4-dihydroxybutyric acid residues in BK223-A (1)

Fig. 1. Structures of $\mathbf{1}, \mathbf{2}$ and $\mathbf{3}$ and the corresponding acetates.

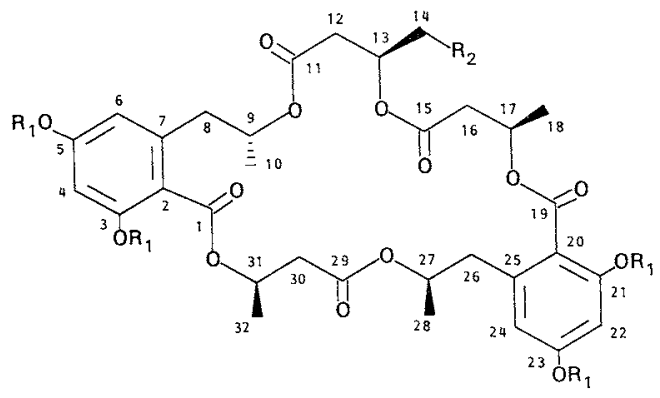

$1 \quad \mathrm{R}_{1}=\mathrm{H}, \mathrm{R}_{2}=\mathrm{OH}$

1a $\mathrm{R}_{1}=\mathrm{Ac}, \mathrm{R}_{2}=\mathrm{OAc}$

$3 \quad \mathrm{R}_{1}=\mathrm{R}_{2}=\mathrm{H}$

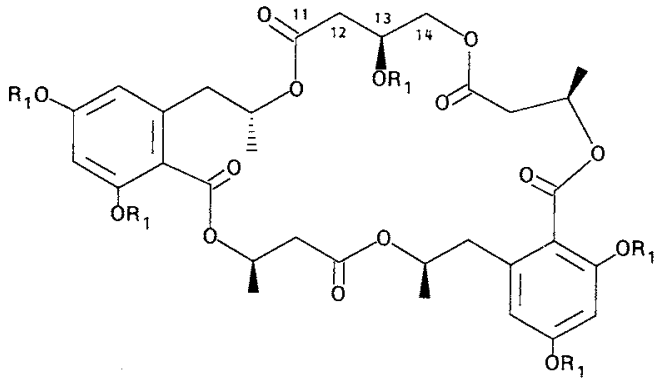

$2 \quad \mathrm{R}_{1}=\mathrm{H}$

2a $\quad R_{1}=A c$

Fig. 2. ${ }^{1} \mathrm{H}$ chemical shifts for the 3,4-dihydroxybutyric acid unit in 1/1a (upper part) and 2/2a (lower part).<smiles>COC(=O)CC(CO)OC(C)=O</smiles>
Acetylation<smiles>[3H]OC(=O)C[C@@H](CC(C)=O)CC(=O)OC</smiles><smiles>COC(=O)CC(O)C(C)OC(=O)C(C)C</smiles><smiles>COC(=O)CC(COC(C)=O)OC(C)=O</smiles> 
and $-\mathrm{B}$ (2) (C13) was determined by the method described for oscillatoxin A by MoOre et al. ${ }^{6}$. Thus acid hydrolysis of $\mathbf{1}$ and $\mathbf{2}$ followed by vacuum distillation and silica gel chromatography yielded a compound identified as ( $S$ )-3,4-dihydroxybutyric acid- $\gamma$-lactone by comparison of its physical and spectroscopic data with literature values ${ }^{6}$. The absolute configurations at the five chiral centers are therefore $(9 R, 13 S, 17 R, 27 R, 31 R)$ for BK223-A (1) and $-\mathrm{B}(2)$, and $(9 R, 13 R, 17 R, 27 R, 31 R)$ for $\mathrm{BK} 223-\mathrm{C}$ (3).

During the preparation of this manuscript Mizoue et al. ${ }^{1)}$ published the structures of two novel potentiators of nerve growth factor. The compounds were isolated from Penicillium verruculosum F-4542 and designated NG-011 and NG-012. The overall structure of NG-012 is identical to the one we propose for BK223-A. BK223-A and BK223-B differ in being regioisomers, where NG-011 is an epimer of NG-012. Hence, both BK223-B and -C seem to be novel.

\section{Biological Activities}

The in vitro growth inhibitory effect against a selection of important plant pathogenic fungi was examined for 1, 2 and 3. The results are summarized in Table 4 (see Experimental for definition of activities). 1 and 2 have similar spectra of activity, but with 1 being more potent than 2.3 showed somewhat lower specific activity than both 1 and 2 , but with a broader spectrum of activity.

The cytotoxic properties of 1,2 and 3 were determined in a mouse peritoneal macrophage assay and showed $\mathrm{IC}_{50}$ values for cellular ATP (viability) and chemiluminescence (phagocytosis) to be: 1, 2.5 and $2.0 \mu \mathrm{g} / \mathrm{ml} ; 2,6$ and $6 \mu \mathrm{g} / \mathrm{ml} ; 3$, both $<10 \mu \mathrm{g} / \mathrm{ml}$.

\section{Experimental}

\section{General}

Analytical HPLC was carried out using a Waters $600 \mathrm{E}$ gradient pump, a Waters 994 photo diode array detector and a Waters 700 WISP autosampler and using the Maxima software for system control and data handling. For preparative HPLC Gilson 305/306 master/slave pumps and a Pye Unicam LC3 UV-detector was used. Optical rotations were measured on a Perkin-Elmer 241 polarimeter. Mass spectra were obtained using an VG70-250SE instrument (VG Analytical), using cesium ion bombardment at $12 \mathrm{kV}$ and detecting positive ions. 2-Hydroxyethyl disulfide was used as matrix. Gas chromatography-mass spectrometry (GC/MS) was carried out on a system consisting of a HP5890 Series II gas chromatograph directly coupled to a JEOL JMS-AX505W mass spectrometer. The GC-column was an HP Ultra 2; oven program: $100^{\circ} \mathrm{C}$ for 1 minute, $100 \sim 170^{\circ} \mathrm{C}$ at $15^{\circ} \mathrm{C} /$ minute, $170 \sim 275^{\circ} \mathrm{C}$ at $10^{\circ} \mathrm{C} /$ minute, $275^{\circ} \mathrm{C}$ for 14 minutes. Identifications were done using the NIST library and in the case of 3-hydroxybutyric acid confirmed by running the authentic sample for confirmation of retention time and mass spectrum.

NMR-spectra were obtained on a Bruker AC300P instrument equipped with a ${ }^{1} \mathrm{H}^{-13} \mathrm{C}$-dual probe operating at 300.13 and $75.47 \mathrm{MHz}$ for ${ }^{1} \mathrm{H}$ and ${ }^{13} \mathrm{C}$, respectively. All spectra were recorded at $297 \mathrm{~K}$. ${ }^{1} \mathrm{H}$-detected experiments were performed using the probe with conventional geometry. Solvent peaks $\left(7.27 \mathrm{ppm}\left({ }^{1} \mathrm{H}\right)\right.$ and $\left.77.00 \mathrm{ppm}\left({ }^{13} \mathrm{C}\right)\right)$ were used for scaling spectra recorded in chloroform- $d_{1}$. TMS was used for spectra acquired in acetone- $d_{6}$. 
Fermentation

Cultivation of the Strain

Penicillium verruculosum (IMI 352119) may be grown on slants containing YPG-1 agar prepared by

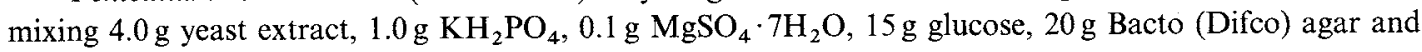
adding distilled water to 1 liter. The substrate was autoclaved at $121^{\circ} \mathrm{C}$ for 40 minutes. The slants were incubated at $25^{\circ} \mathrm{C}$ for 7 days or longer.

\section{Surface Cultivation}

Penicillium verruculosum IMI 352119 was grown in Erlenmeyer flasks $(500 \mathrm{ml})$ containing $100 \mathrm{ml}$ of YES agar. The medium contained the following ingredients: yeast extract $(2 \%)$, sucrose $(15 \%)$, agar ( $2 \%)$, $\mathrm{CuSO}_{4}$ and $\mathrm{ZnSO}_{4}\left(5 \mathrm{ppm}\right.$ and $10 \mathrm{ppm}$, respectively). The substrate was autoclaved at $121^{\circ} \mathrm{C}$ for 40 minutes. One drop of spores was used to inoculate each flask. The flasks were incubated at $25^{\circ} \mathrm{C}$ for 14 days. The extraction of the metabolites was performed by addition of methanol $(200 \mathrm{ml}$ per flask $)$ and shaking at $18^{\circ} \mathrm{C}$ overnight. The extract was centrifuged and the supernatant processed as described below.

\section{Submerged Cultivation}

For submerged fermentation the substrate was prepared by mixing $20 \mathrm{~g}$ yeast extract (Difco), $150 \mathrm{~g}$ sucrose, $1 \mathrm{ml}$ trace metal solution $\left(8.9 \mathrm{~g} \mathrm{ZnSO}_{4} \cdot 7 \mathrm{H}_{2} \mathrm{O}\right.$ and $3.9 \mathrm{~g} \mathrm{CuSO}_{4} \cdot 5 \mathrm{H}_{2} \mathrm{O}$ dissolved in $500 \mathrm{ml}$ distilled water) and adding distilled water to 1 liter. The $\mathrm{pH}$ was adjusted to 6.4 using $4 \mathrm{M} \mathrm{HCl}$ and the substrate was autoclaved at $121^{\circ} \mathrm{C}$ for 20 minutes. Each Erlenmeyer flask $(500 \mathrm{ml})$ containing $100 \mathrm{ml}$ substrate was inoculated with approx $10^{6}$ spores from a YPG-1 agar slant. The flasks were shaken $(230 \mathrm{rpm})$ for 7 days at $25^{\circ} \mathrm{C}$. The mycelium was separated by centrifugation and extracted with ethanol $(100 \mathrm{ml}$ per flask).

\section{Isolation of Metabolites}

The methanolic extract ( 3.5 liters centrifugate) from 20 surface fermentation flasks was concentrated under reduced pressure to $50 \mathrm{ml}$. After addition of $200 \mathrm{ml}$ of water, the aqueous phase was extracted three times with $100 \mathrm{ml}$ portions of EtOAc. The organic phases were combined and dried by freezing $\left(-18^{\circ} \mathrm{C}\right.$ over night). The separated ice was removed by filtration. Evaporation to dryness yielded $2 \mathrm{~g}$ of a dark brown extract.

The primary extract was subjected to reversed phase HPLC (LiChroPrep RP18 15 25 $\mu \mathrm{m}$, $20 \times 230 \mathrm{~mm}$, linear gradient from $40 \%$ methanol to $100 \%$ methanol ( 80 minutes), flowrate $10 \mathrm{ml} / \mathrm{minute}$, detected by UV absorption at $225 \mathrm{~nm})$ to yield three fractions: Fraction $\mathrm{I}(45 \mathrm{mg})$ mixture of 1 and $2(9: 1)$, Fraction II (216 mg) mixture of compounds 1 and 2 (1:1), Fraction III (28 mg) compound 3. Rechromatography of Fraction III in the same system yielded pure 3 as an amorphous glass (18 $\mathrm{mg}$ ). The compounds 1 and 2 were purified to homogeneity by further HPLC separation of Fractions I and II (LiChroPrep RP18 $7 \mu \mathrm{m}, 10 \times 250 \mathrm{~mm}$, isocratic $57 \%$ acetonitrile buffered with $0.01 \% \mathrm{TFA}, 1.5 \mathrm{ml} / \mathrm{minute}$, detected by UV absorption at 225 and $300 \mathrm{~nm}$ ). Both $\mathbf{1}$ and $\mathbf{2}$ were obtained as amorphous foam (128 and $52 \mathrm{mg}$, respectively).

The purity of the compounds was checked by analytical HPLC with the following conditions: Column: LiChroSorb RP18 $250 \times 4.6 \mathrm{~mm}(10 \mu \mathrm{m})$; Eluent A: $30 \%$ acetonitril $(0.05 \%$ TFA), Eluent B: $100 \%$ acetonitril $(0.05 \%$ TFA). Linear gradient from $0 \% \mathrm{~B}$ to $75 \% \mathrm{~B}$ over 15 minutes, flowrate $1.5 \mathrm{ml} / \mathrm{minute}$. Detection by UV-absorbance at 210 and $300 \mathrm{~nm}$. The retention times for 1,2 and 3 are 11.1, 11.4 and 14.1 , respectively. Retention indices in the system of FRISVAD and THRANE ${ }^{3)}$ are $1054 \sim 1062,1080 \sim 1083$ and 1196 , respectively. UV data in the water acetonitril gradient: $\lambda_{\max }(\mathrm{nm}) 215(100 \%), 262(48 \%)$ and $299(20 \%), \lambda_{\min }(\mathrm{nm}) 240(18 \%) 284(16 \%)$.

\section{Bioassays}

The test organisms were: Phoma lingam DSM 62910, Monilinia fructigena ATCC 24976, Alternaria alternata ATCC 44500, Sclerotinia sclerotiorum, Phoma betae, Botrytis cinerea, Ascochyta pisi and Pyrenophora teres (where no strain number is given the isolate belongs to the Novo Nordisk A/S strain collection, Copenhagen). The test organisms were transferred to potato dextrose bouillon and incubated for 7 days at $25^{\circ} \mathrm{C}$. The mycelium was harvested and homogenized for 10 seconds in a blender. $1 \mathrm{ml}$ suspension was transferred to petri dishes, added $20 \mathrm{ml}$ potato dextrose agar (Difco) at $45^{\circ} \mathrm{C}$ and mixed 
thoroughly. After cooling $4 \mathrm{~mm}$ wells were punched and $15 \mu \mathrm{l}$ of test solutions containing various concentrations of 1, 2 and 3 dissolved in ethanol were applied to each well. The plates were incubated for three days at $25^{\circ} \mathrm{C}$ and the inhibition zones observed. Four levels of activity were defined: strong $(+++)$, if the minimal concentration required to give a measureable inhibition zone was less than $10 \mu \mathrm{g} / \mathrm{ml}$; weak $(+)$, if the concentration required was more than $250 \mu \mathrm{g} / \mathrm{ml}$ and medium $(++)$ for activities in between. No activity $(-)$ means no inhibition zone observed at concentrations less than $1,000 \mu \mathrm{g} / \mathrm{ml}(1,000 \mu \mathrm{g} / \mathrm{ml}$ was highest concentration applied).

\section{Hydrolysis and Derivatization for GC/MS-analysis}

\section{Trimethylsilyl Derivatives}

$1 \mathrm{mg}$ of 1 was dissolved in $3 \mathrm{ml}$ of $50 \%$ aqueous $\mathrm{MeOH}$ and treated for 20 hours with $1 \mathrm{ml}$ of Amberlite IRA-904 $\left(\mathrm{OH}^{-}\right)$anion resin at room temperature. The resin was filtered off and washed twice with $2 \mathrm{ml} 1 \mathrm{M}$ acetic acid and $\mathrm{MeOH}$. The filtrate and washings were combined and evaporated to dryness in a vacuum centrifuged. The sample for GC/MS analysis was prepared by treating the residue with BSTFA in a closed vial for 10 minutes at $100^{\circ} \mathrm{C}$ and diluting with DMF. GC/MS-conditions as described above.

\section{$(S)$-Phenylethylisocyanate Derivatives}

$1 \mathrm{mg} 1$ was dissolved in $200 \mu \mathrm{l} \mathrm{EtOH}$ acidified with $\mathrm{H}_{2} \mathrm{SO}_{4}(36 \mathrm{ml}$ EtOH and $1.1 \mathrm{ml}$ concentrated sulfuric acid) and added $200 \mu \mathrm{l} 1,2$-dichloroethane. The sample was heated in a closed vial to $100^{\circ} \mathrm{C}$ for 15 hours. After cooling to room temperature $500 \mu \mathrm{l}$ distilled water and $500 \mu \mathrm{l}$ saturated aqueous $\mathrm{NaCl}$ was added followed by extraction three times with $1 \mathrm{ml}$ portions of ether. The combined organic phases were washed with saturated aqueous $\mathrm{NaHCO}_{3}(1 \mathrm{ml})$ and saturated aqueous $\mathrm{NaCl}(1 \mathrm{ml})$. The ether phase was dried by filtration through a layer of anhydrous $\mathrm{MgSO}_{4}$ in a pasteur pipette and the solvent removed in a stream of nitrogen. The residue was added $10 \mu \mathrm{l}(S)$-phenylethylisocyanate and heated to $125^{\circ} \mathrm{C}$ for 5 hours. The mixture was dissolved in $2 \mathrm{ml}$ dichloromethane for GC-analysis (column HP-4, $50 \mathrm{~m} \times 0.25 \mathrm{~mm}$, carrier gas $\mathrm{H}_{2}(40 \mathrm{~m} /$ second $)$, temperature $\left.220^{\circ} \mathrm{C}\right)$.

\section{Isolation of (3R)-3,4-Dihydro-6,8-dihydroxy-3-methyl-isocoumarin}

$10 \mathrm{mg} 1$ was hydrolyzed in $0.5 \mathrm{M}$ aqueous $\mathrm{NaOH}$ for 20 hours under nitrogen in a closed vial at room temperature. After acidifying with $4 \mathrm{M}$ aqueous $\mathrm{HCl}$ the solution was extracted twice with $2 \mathrm{ml}$ portions of EtOAc. The extract was dried $\left(\mathrm{Na}_{2} \mathrm{SO}_{4}\right)$ and evaporated in a stream of nitrogen. (3R)-3,4-dihydro-6,8dihydroxy-3-methyl-isocoumarin ( $1.8 \mathrm{mg}$, crystalline mass) was isolated by reversed phase HPLC (ODS $16 \times 250 \mathrm{~mm}$, linear gradient from water to $50 \%$ acetonitrile, both buffered with $0.05 \%$ TFA). ${ }^{1} \mathrm{H}$ NMR $\left(\mathrm{CDCl}_{3}\right): 1.52(3 \mathrm{H}, \mathrm{d}, 6.3), 2.87(2 \mathrm{H}, \mathrm{AB}-\mathrm{syst}),. 4.69(1 \mathrm{H}, \mathrm{m}), 6.21(1 \mathrm{H}, \mathrm{d}, 2.4), 6.33(1 \mathrm{H}, \mathrm{d}, 2.4), 11.22$ $(1 \mathrm{H}, \mathrm{s}, \mathrm{OH}) ;{ }^{13} \mathrm{C} \mathrm{NMR}\left(\mathrm{CDCl}_{3}\right): 169.8,164.5,162.2,141.7,106.4,102.0,75.5,34.8,20.7 ; \mathrm{EI}-\mathrm{MS} \mathrm{m} / \mathrm{z} 194$ $\left(\mathrm{M}^{+}\right)$: $\mathrm{mp} 198 \sim 201^{\circ} \mathrm{C},[\alpha]_{\mathrm{D}}^{22}-57^{\circ}(c 0.07, \mathrm{MeOH})\left(\mathrm{litt}^{4)} \mathrm{mp} 214 \sim 217^{\circ} \mathrm{C},[\alpha]_{\mathrm{D}}^{20}-63^{\circ}(c 0.6, \mathrm{EtOH})\right)$.

\section{Acetylation of BK223-A (1) to 1a}

$3.6 \mathrm{mg} 1$ was dissolved in $0.5 \mathrm{ml}$ of pyridine and added $0.3 \mathrm{ml}$ acetic anhydride under cooling in ice bath. After two hours at room temperature excess reagent was destroyed by addition of $1 \mathrm{ml}$ of crushed ice and acidification with $4 \mathrm{M}$ sulfuric acid. After stirring for 10 minutes, the mixture was extracted twice with $2 \mathrm{ml}$ portions of dichloromethane. The combined extracts were washed with $2 \times 1 \mathrm{ml}_{2} \mathrm{M} \mathrm{H}_{2} \mathrm{SO}_{4}, 1 \mathrm{ml}$ $\mathrm{H}_{2} \mathrm{O}$ and $1 \mathrm{ml}$ saturated aqueous $\mathrm{NaHCO}_{3}$ and dried $\left(\mathrm{Na}_{2} \mathrm{SO}_{4}\right)$. The solvent was evaporated and the product purified by preparative TLC (Merck silica, $20 \times 20 \mathrm{~cm}, 2 \mathrm{~mm}$ layer) using chloroform - MeOH $(50: 1)$ as eluent, to give $2.1 \mathrm{mg}$ of the pentaacetate (1a) as an amorphous solid, LSIMS $873\left(\mathrm{MH}^{+}\right) .{ }^{1} \mathrm{H}$ NMR $(\delta$, multiplicity, $J \mathrm{~Hz})$ in $\mathrm{CDCl}_{3}: 6.93(1 \mathrm{H}, \mathrm{d}, 2.2), 6.90(1 \mathrm{H}, \mathrm{d}, 2.2), 6.88(1 \mathrm{H}, \mathrm{d}, 2.2), 6.84(1 \mathrm{H}, \mathrm{d}$, 2.2), $5.55(2 \mathrm{H}, \mathrm{m}), 5.47(1 \mathrm{H}, \mathrm{m}), 5.02(1 \mathrm{H}, \mathrm{m}), 4.95(1 \mathrm{H}, \mathrm{m}), 4.37(1 \mathrm{H}, \mathrm{dd}, 4 / 12), 4.08(1 \mathrm{H}, \mathrm{dd}, 5 / 12), 3.07$ $(1 \mathrm{H}, \mathrm{dd}, 5 / 14), 2.96(1 \mathrm{H}, \mathrm{dd}, 7 / 16), 2.95(1 \mathrm{H}, \mathrm{dd}, 8 / 15), 2.75(1 \mathrm{H}, \mathrm{dd}, 8 / 17), 2.70(1 \mathrm{H}, \mathrm{dd}, 8 / 16), 2.62(2 \mathrm{H}$, $\mathrm{d}, 7), 2.58(1 \mathrm{H}, \mathrm{dd}, 8 / 13), 2.56(1 \mathrm{H}, \mathrm{dd}, 4 / 16), 2.55(1 \mathrm{H}, \mathrm{dd}, 4 / 16), 2.29(3 \mathrm{H}, \mathrm{s}), 2.26(3 \mathrm{H}, \mathrm{s}), 2.25(2 \times 3 \mathrm{H}$, s), $2.24(3 \mathrm{H}, \mathrm{s}), 2.05(3 \mathrm{H}, \mathrm{s}), 1.39(3 \mathrm{H}, \mathrm{d}, 6.2), 1.38(3 \mathrm{H}, \mathrm{d}, 6.2), 1.28(3 \mathrm{H}, \mathrm{d}, 6.2), 1.06(3 \mathrm{H}, \mathrm{d}, 6.2)$. 
Acetylation of BK223-B (2) to 2a

$5.0 \mathrm{mg} 2$ was acetylated as described above for 1 . After preparative TLC $4.1 \mathrm{mg}$ of product (2a) was obtained. LSIMS $873\left(\mathrm{MH}^{+}\right),{ }^{1} \mathrm{H}$ NMR in $\mathrm{CDCl}_{3}: 6.94(1 \mathrm{H}, \mathrm{d}, 2.2), 6.88 \sim 6.90(3 \mathrm{H}, 3 \times \mathrm{d}, \mathrm{s}), 5.58(1 \mathrm{H}$, $\mathrm{m}), \quad 5.55(1 \mathrm{H}, \mathrm{m}), 5.34(1 \mathrm{H}, \mathrm{m}), 5.10(1 \mathrm{H}, \mathrm{m}), 5.09(1 \mathrm{H}, \mathrm{m}), 4.35(1 \mathrm{H}, \quad \mathrm{dd}, \quad 4.0 / 12)$, $4.09(1 \mathrm{H}, \mathrm{dd}, 5.6 / 12), 3.07(1 \mathrm{H}, \mathrm{dd}, 8 / 14), 3.06(1 \mathrm{H}, \mathrm{dd}, 7 / 14), 2.90(1 \mathrm{H}, \mathrm{dd}, 6 / 14), 2.85(1 \mathrm{H}, \mathrm{dd}, 6 / 14)$, $2.79(1 \mathrm{H}, \mathrm{dd}, 7 / 16), 2.78(1 \mathrm{H}, \mathrm{dd}, 8 / 16), 2.61(1 \mathrm{H}$, not determined $), 2.60(2 \mathrm{H}, \mathrm{d}, 6.5), 2.57(1 \mathrm{H}$, not determined), $2.28(2 \times 3 \mathrm{H}, \mathrm{s}), 2.26(3 \mathrm{H}, \mathrm{s}), 2.25(3 \mathrm{H}, \mathrm{s}), 2.01(3 \mathrm{H}, \mathrm{s}), 1.41(3 \mathrm{H}, \mathrm{d}, 6.3), 1.40(3 \mathrm{H}, \mathrm{d}, 6.3)$, $1.24(3 \mathrm{H}, \mathrm{d}, 6.3), 1.18(3 \mathrm{H}, \mathrm{d}, 6.2)$.

(S)-3,4-Dihydroxybutyric Acid- $\gamma$-lactone from 1 and $\mathbf{2}$

$(S)-3,4-D i h y d r o x y b u t y r i c ~ a c i d-\gamma$-lactone $\left(2.0 \mathrm{mg},[\alpha]_{\mathrm{D}}^{22}-67^{\circ}(\mathrm{MeOH}, c 0.2)\right.$, litt. $^{6)}[\alpha]_{\mathrm{D}}-72^{\circ}(\mathrm{EtOH}$, $c 0.8)$ ) was isolated from the hydrolysis mixture of $1(30 \mathrm{mg})$ by distillation $\left(130^{\circ} \mathrm{C} / 0.2 \mathrm{mmHg}\right)$ and chromatography essentially as described for oscillatoxin ${ }^{6}$. By the same procedure the $(S)$-lactone was isolated from the hydrolysis mixture of $\mathbf{2}$.

\section{References}

1) Ito, M.; Y. Tsuchida, K. Mizoue \& K. HANADA: NG-011 and NG-012, novel potentiators of nerve growth factor. II. The structure determination of NG-011 and NG-012. J. Antibiotics 45: 1566 1572, 1992

2) Stolk, A. C. \& R. A. Samson: The ascomycete genus Eupenicillum and related Penicillium anamorphs. Stud. Mycol. (Baarn) 23: $1 \sim 149,1983$

3) Frisvad, J. C. \& U. ThRanE: Standardized high-perofrmance liquid chromatography of 182 mycotoxins and other fungal metabolites based on alkylphenone retention indices and UV-VIS spectra (diode array detection). J. Chromatogr. 404: 195 214, 1987

4) Curtis, R. F.; P. C. Harries, C. H. Hassall, J. D. Levi \& D. M. Philips: The biosynthesis of phenols. Part X. Mutation and radioactive'tracer studies relating to the biosynthesis of sulochrin. J. Chem. Soc. C 1966: 168 174, 1966

5) Pereira, W.; V. A. Bacon, W. Patton, B. Halpern \& G. E. Pollock: Use of R-(+)-1-phenylethylisocyanate in the optical analysis of asymmetric secondary alcohols by gas chromatography. Anal. Lett. 3: 23 28, 1970

6) Moore, R. E.; A. J. Blackman, C. E. Cheuk, J. S. Mynderse, G. K. Matsumoto, J. Clardy, R. W. Woodard \& J. C. Craig: Absolute stereochemistries of the aplysiatoxins and oscillatoxin A. J. Org. Chem. 49: 2484 2489, 1984 